\title{
Seroprevalence of Leptospira spp in cattle from Monte Negro municipality, western Amazon ${ }^{1}$
}

\author{
Daniel M. Aguiar 2", Solange M. Gennari², Guacyara T. Cavalcante ${ }^{2}$, Marcelo B. \\ Labruna $^{2}$, Silvio A. Vasconcellos ${ }^{2}$, Aline A. R. Rodrigues ${ }^{3}$, Zenaide M. Moraes ${ }^{2}$ \\ and Luis M.A. Camargo ${ }^{4}$
}

\begin{abstract}
Aguiar D.M, Gennari S.M., Cavalcante G.T., Labruna M.B., Vasconcellos S.A., Rodrigues A.A.R., Moraes Z.M. \& Camargo L.M.A. 2006. Seroprevalence of Leptospira spp in cattle from Monte Negro municipality, western Amazon. Pesquisa Veterinária Brasileira 26(2):102-104. Department of Preventive Veterinary Medicine and Animal Health, Faculty of Veterinary Medicine and Animal Production, University of São Paulo, Av. Prof. Orlando Marques de Paiva 87, São Paulo, SP 05508-900, Brazil. E-mail: danmoura@aptaregional.sp.gov.br

The prevalence of anti-Leptospira spp antibodies was investigated in 2,109 female cattle from 86 herds of Monte Negro municipality, Rondônia, Brazil. Sera samples were evaluated by Microscopic Agglutination Test against 24 leptospira serovars. Titers $=100$ for at least one of 24 leptospira serovars were detected in 1,114 cows ( $52.8 \%$ ) from $82(95.3 \%)$ herds. The adjusted overall prevalence for Monte Negro municipality was $53.9 \%$ (49-58.7\%; CI: 95\%). The most prevalent serovars were Hardjo (14.5\%), Wolffi (12.3\%), Shermani (10.8\%), Patoc (7.9\%), and Hebdomadis (6.1\%). Other serovars worldwidely reported like Bratislava, Pomona and Grippotyphosa were detected in low levels.
\end{abstract}

INDEX TERMS: Leptospira spp, cattle, epidemiology, Amazon.

RESUMO.- [Prevalência de anticorpos anti-Leptospira spp em bovinos do município de Monte Negro, Amazônia Ocidental.] Foi investigada a prevalência de anticorpos anti-Leptospira spp em 2.109 vacas provenientes de 86 rebanhos do município de Monte Negro, Rondônia, Brasil. As amostras de soro sanguíneo foram avaliadas pelo Teste de Aglutinação Microscópica frente a 24 sorovares de leptospira. Títulos $=100$ para um ou mais sorovares foram detectados em 1.114 vacas $(52,8 \%)$ de $82(95,3 \%)$ rebanhos. A prevalência ajustada para o município de Monte Negro foi de 53,9\% (I.C.: 95\%; 49-58,7\%). Os sorovares mais prevalentes foram Hardjo (14,5\%), Wolffi $(12,3 \%)$, Shermani $(10,8 \%)$, Patoc $(7,9 \%)$ e Hebdomadis $(6.1 \%)$. Outros sorovares mundialmente relatados como Bratislava, Pomona e Grippotyphosa foram pouco detectados.

TERMOS DE INDEXAÇÃO: Leptospira spp, bovinos, epidemiologia, Amazônia.

\footnotetext{
1 Received on August 10, 2005.

Accepted for publication on October 23, 2005.

${ }^{2}$ Department of Preventive Veterinary Medicine and Animal Health, Faculty of Veterinary Medicine and Animal Production, University of São Paulo (USP), Av. Prof. Orlando Marques de Paiva, 87, São Paulo, SP 05508-900, Brazil. * Author for correspondence. E-mail: danmoura@aptaregional.sp.gov.br

3 Department of Animal Reproduction, FMV, USP, São Paulo, SP.

${ }^{4}$ Biomedical Science Institute, USP, Campus Monte Negro, RO.
}

\section{INTRODUCTION}

Leptospirosis infection has been reported as a cause of economic losses on beef and dairy cattle. Infected herds present reproductive failures as abortion, infertility, sterility, stillbirth or weak calves and agalactia. Furthermore, it is one of the most important zoonoses in the world (Radostits et al. 2000). Additionally, leptospirosis is found worldwidely and its seroprevalence could be different according to herds, areas, and countries. Water is the main vehicle for spreading the agent in the environment, making tropical highly suitable for maintenance of Leptospira serovars (Radostits et al. 2000).

The Brazilian Amazon region, the largest forest biome of the world, is a new frontier where agricultural development and livestock activities have been attempted. The state of Rondônia is a developing area in the western Amazon of Brazil, where very few information about the occurrence of leptospirosis in cattle herds have been reported (Homem et al. 2000). The present study evaluated the prevalence of anti-Leptospira spp antibodies in cattle, from Monte Negro municipality, Rondônia.

\section{MATERIALS AND METHODS}

In late 2001, Monte Negro municipality ( $\left.10^{\circ} 15^{\prime} 35^{\prime \prime} S, 63^{\circ} 18^{\prime} 06^{\prime \prime} \mathrm{W}\right)$ had 722 cattle farms ( 722 herds) comprising 116,736 bovines. Nelore was the predominant beef breed whereas dairy cattle were crossbred of zebu and several European breeds. The region has a hot and wet 
climate, with high levels of precipitation that achieve $2,000 \mathrm{~mm}$ annually, with a moderate drought period from April to September. Temperature ranges from 25 to $29^{\circ} \mathrm{C}$ and the relative humidity from $70 \%$ to $80 \%$ throughout the year. In this region, cattle are not vaccinated against leptospirosis.

The number of farms to be investigated in the present was calculated by Epilnfo 6.04 with $50 \%$ of estimated prevalence, $10 \%$ of absolute precision desired, and $95 \%$ of confidence interval. Then the minimum number of farms obtained was 86 . Each farm represented one herd. The number of cows tested on each farm was calculated with $95 \%$ confidence of detecting at least one seropositive animal per farm with at least $5 \%$ of seropositive cows in the herd (Thrusfield 1995).

Serum samples from the 86 farms were collected from May to October 2002 and stored at $-20^{\circ} \mathrm{C}$. The farm sample was composed of 11 beef, 50 dairy and 25 mixed cattle herds. Serum samples were analyzed by Microscopic Agglutination Test (MAT; Galton et al. 1965, Cole Junior et al. 1973) with the cut off 1:100 dilution against 24 leptospira serovars (Andamana, Australis, Autumnalis, Bataviae, Bratislava, Butembo, Canicola, Castellonis, Cinoptery, Copennhageni, Grippotyphosa, Hardjo, Hebdomadis, Icterohaemorrhagiae, Javanica, Panama, Pomona, Patoc, Pyrogenes, Sentot, Shermani, Tarassovi, Wolffi and Whitcombi) cultivated in modified EMJH medium (Alves et al. 1996). Positive sera were retested against each reactant serovar in two fold serial dilutions. The serum titer was the reciprocal of the highest serum dilution that presented $50 \%$ of agglutination. The most probable serovar was the one that presented the highest titer. When one animal presented the same highest titer for two or more serovars it was not included in the analyses of the most probable serovar.

Prevalence of leptospirosis was calculated by herd and by animals. As we evaluated herds with different sizes, the overall prevalence was adjusted by herd size (Thrusfield 1995). Animal prevalence values were also determined separately for herds allocated in each of the three different kinds of management: dairy, beef or mixed herds. Prevalence values among beef, dairy and mixed herds were compared by the Chi-Square test $\left(\mathrm{c}^{2}\right)$. These calculations were generated by using the Epiinfo 6.04 program.

\section{RESULTS}

Serum samples were collected from 2,109 cows from 86 farms, being 584 from beef, 1,011 from dairy, and 514 from mixed herds. At least one seropositive animal was detected in each of 82 herds, giving a herd prevalence of $95.3 \%$ (88.5-98.7\%; Cl: 95\%). A total of 1,114 cows (52.8\%) presented antibodies against one or more serovar studied (Table 1). The adjusted overall prevalence of Leptospira spp seropositive cows for Monte Negro municipality was 53.9\% (49-58.7\%; CI: 95\%).

Table 1. Serological results of anti-Leptospira spp antibodies among cattle from $\mathbf{8 6}$ herds of the rural area of Monte Negro municipality, Rondonia, Brazilian western Amazon

\begin{tabular}{cccccccc}
\hline Production & \multicolumn{5}{c}{ Leptospira spp antibodies } \\
\cline { 2 - 4 } \cline { 3 - 4 } \cline { 6 - 8 } & Positive & Examined & $\%^{*}$ & & \multicolumn{3}{c}{ Animal } \\
Beef & 11 & 11 & $100.0^{\mathrm{b}}$ & & 364 & 584 & $58.7^{\mathrm{a}}$ \\
Dairy & 47 & 50 & $94.0^{\mathrm{b}}$ & & 482 & 1,011 & $49.6^{\mathrm{b}}$ \\
Mixed & 24 & 25 & $96.0^{\mathrm{b}}$ & & 268 & 514 & $52.3^{\mathrm{b}}$ \\
Total & 82 & 86 & 95.3 & & 1,114 & 2,109 & 52.8
\end{tabular}

* Different letters in the same column: $\mathrm{P}<0.05$.
Table 2. Animal and herd seroprevalence according to different Leptospira serovars among cattle from Monte Negro municipality, Rondonia, Brazilian_western Amazon

\begin{tabular}{|c|c|c|c|c|}
\hline \multirow[t]{2}{*}{ Leptospira serovar } & \multicolumn{2}{|c|}{ Positive animal } & \multicolumn{2}{|c|}{ Positive herd } \\
\hline & Number & $\%$ & Number & $\%$ \\
\hline Hardjo & 162 & 14.5 & 37 & 45.0 \\
\hline Wolffi & 137 & 12.3 & 47 & 57.3 \\
\hline Shermani & 120 & 10.8 & 49 & 60.0 \\
\hline Patoc & 88 & 7.9 & 43 & 52.4 \\
\hline Hebdomadis & 68 & 6.1 & 28 & 34.1 \\
\hline Bratislava & 44 & 3.9 & 25 & 30.5 \\
\hline Autumnalis & 31 & 2.8 & 23 & 28.0 \\
\hline Pyrogenes & 22 & 2.0 & 16 & 19.5 \\
\hline Castellonis & 17 & 1.5 & 14 & 17.0 \\
\hline Canicola & 16 & 1.4 & 12 & 14.6 \\
\hline Pomona & 14 & 1.3 & 12 & 14.6 \\
\hline Australis & 11 & 1.0 & 09 & 10.9 \\
\hline Butembo & 10 & 0.9 & 08 & 9.7 \\
\hline Whitcombi & 06 & 0.6 & 05 & 6.1 \\
\hline Grippotyphosa & 04 & 0.4 & 04 & 4.9 \\
\hline Icterohaemorrhagiae & 04 & 0.4 & 04 & 4.9 \\
\hline Copennhageni & 04 & 0.4 & 03 & 3.6 \\
\hline Not characterized reaction* & 356 & 31.8 & 02 & 2.4 \\
\hline
\end{tabular}

* Identical highest titer for two or more serovars.

A total of $32 \%(n=356)$ of the seropositive cows had antibodies against more than one serovar studied, without most probable characterization. The serovars Hardjo, Wolffi and Shermani were detected as the more prevalent. Each serovar reported in the present study with result by animals and herds are summarized in Table 2.

\section{DISCUSSION}

The present study shows a herd prevalence of $95.3 \%$ for Leptospira infection, which is similar to the value of $97 \%$ reported in another study conducted in the State of Pará, eastern Brazilian Amazon (Homem et al. 2000). In contrast, in a similar study in Spain, Alonso-Andicoberry et al. (2001) reported $42.8 \%$ of herds with leptospirosis. These differences between Brazil and Spain could be explained by the climatic diversity of the related areas, since in the tropical wet areas the survival of Leptospira serovars in the environment could be longer than in other non-tropical areas (Radostits et al. 2000).

In the present study, prevalence by animal was estimated to be $53.9 \%$, which is similar to another study conducted in the Amazon region of Brazil (State of Pará) which detected $66.2 \%$ of seropositive cattle (Negrão et al. 1999). The proportion of seropositive cattle was significantly higher $(\mathrm{P}<0.05)$ for beef cattle (58.7\%) than in dairy $(49.6 \%)$ and mixed herds $(52.3 \%)$. These results agree with Miller et al. (1991) in the USA and Vasconcellos et al. (1997) in Brazil.

The most-prevalent serovar by animal in the investigated area was Hardjo. Studies conducted in other regions of Brazil found similar results (Brod et al. 1994, Lilenbaum \& Santos 1996, Vasconcellos et al. 1997, Ribeiro et al. 2000). Serovar Hardjo is usually the most-prevalent in cattle worldwidely and is considered the most adapted to cattle (Radostits et al. 2000).

Shermani was the most prevalent serovar among the 86 herds of the present study. There is little information about this serovar 
in domesticated animals. It is known that Shermani is maintained by wild rodents and has frequently been found in serological studies in the northern area of Brazil (Negrão et al. 1999, Homem et al. 2000). The second most prevalent serovar in animals and herds was Wolffi. Probably, as Wolffi and Hardjo serovars belong to the same serogroup (Sejroe); this result could be assumed as cross-reactions (Faine, 1982). Patoc was the fourth and third most prevalent serovar by animals and herds respectively. This serovar has been reported only once in Brazil (Negrão et al. 1999). This serovar belongs to the Leptospira biflexa group and is frequently used in serological investigations as genus specific antigen, due to its cross-reactions with pathogenic serovars that could be detected earlier in the infection course by pathogenic serovar (Mauermann et al. 1993). Other serovars worldwidely reported like Bratislava, Pomona and Grippotyphosa occurred at low frequencies. Nevertheless, these serovars have been frequently found in southeastern, midwestern and northeastern Brazil (Vasconcellos et al. 1997, Negrão et al. 1999, Ribeiro et al. 1999, Langoni et al. 2000).

The present study showed the relevance of Leptospira spp infection among cattle in the Brazilian Amazon, with emphasis on the serovars Hardjo and Shermani.

Acknowledgements.- We are grateful to Dr. F. Ferreira (Faculty of Veterinary Medicine, São Paulo University); to T. Bronhal and to the Agency of Animal Sanitary Defense of the State of Rondônia. This work was supported by the Fapesp. D.M. Aguiar, S.M. Gennari and S.A. Vasconcellos are in receipt of a scholarship from CNPq and G.T. Cavalcante from Capes.

\section{REFERENCES}

Alonso-Andicoberry C., Garcia-Peña FJ., Pereira-Bueno J., Costas E. \& OrtegaMora L.M. 2001. Herd-level risk factors associated with Leptospira spp. seroprevalence in dairy and beef cattle in Spain. Prev. Vet. Med. 52(2):109117.

Alves C.J., Vasconcellos S.A., Camargo C.R.A. \& Morais Z.M. 1996. Influência de fatores ambientais sobre a proporção de caprinos soro-reatores para a leptospirose em cinco centros de criação do estado da Paraíba, Brasil. Arqs Inst. Biológico, São Paulo, 63(2):11-18.

Brod C.S., Martins L.F.S., Nussbaum J.R., Fehlberg M.F.B., Furtado L.R.I. \& Rosado R.L.I. 1994. Leptospirose bovina na região sul do Estado do Rio Grande do Sul. Hora Vet., Porto Alegre, 14(84):15-20.
Cole Junior J.R., Sulzer C.R. \& Pursell A.R. 1973. Improved Microtechnique for the Leptospiral Microscopic Agglutination Test. Appl. Microbiol. 25:970-980.

Faine S. 1982. Guidelines for the control of leptospirosis. 2nd ed. World Health Organization, Genève. 171p.

Galton M.M., Sulzer C.R., Santa Rosa C.A. \& Fields M.J. 1965. Application of a microtechnique to the Agglutination Test for Leptospiral Antibodies. Appl. Microb. 13:81-85.

Homem V.S.F., Heinemann M.B., Moraes Z.M., Vianna M.C.B., Silva J.C.R., Sakamoto S.M. Pinheiro S.R., Veiga J.B., Lau H.D., Quanz D., Tourrand J.F., Ferreira F. \& Ferreira Neto J.S. 2000. Leptospirose bovina em Uruará, PA, município da Amazônia Oriental. Arqs Inst. Biológico, São Paulo, 67 (1):1-8.

Langoni H., Meireles L.R., Gottschalk S., Cabral K.G. \& Da Silva A.V. 2000. Perfil sorológico da Leptospirose bovina em regiões do Estado de São Paulo. Arqs Inst. Biológico, São Paulo, 67 (1):37-41.

Lilenbaum W. \& Santos M.R.C. 1996. Effect of management systems on the prevalence of bovine leptospirosis. Rio de Janeiro. Vet. Rec. 138(23):570571.

Mauermann U., Wiegand D. \& Manz D. 1993. Use of nonpathogenic Leptospira strains as diagnostic antigens for detection of Leptospira infection in cattle. Berl. Münch. Tierärztl. Wochenschr. 106:296-299.

Miller D.A., Wilson M.A. \& Beran G.W. 1991. Survey to estimate prevalence of Leptospira interrogans infection in mature cattle in the United States. Am. J. Vet. Res. 52(11):1761-1768.

Negrão A.M.G., Molnár E. \& Molnár L. 1999. Dados sorológicos da leptospirose bovina em algumas regiões do estado do Pará. Revta Bras. Reprod. Anim. 23:406-407.

Radostits O.M., Gay C.C., Blood D.C. \& Hinchcliff K.W. 2000. Veterinary Medicine. 9th ed. W.B. Saunders, Baltimore. 1877p.

Ribeiro S.C.A., Bisinoto D.P. \& Oliveira P.R. 2000. Prevalência da leptospirose em fêmeas reprodutoras bovinas do município de Uberlândia, MG. Vet. Notícias, Uberlândia, 6(1):69-75.

Ribeiro S.C.A., Boscolo I.B., Gonçalves G.F. \& Oliveira P.R. 1999. Leptospirose no rebanho bovino da subregião de Nhecolândia, pantanal matogrossense, Brasil. Vet. Notícias, Uberlândia, 5(1):51-55.

Thrusfield M. 1995. Veterinary Epidemiology. 2nd ed. Blackwell, Cambridge. 479p.

Vasconcellos S.A., Barbarini Júnior O., Umehara O., Morais Z.M., Cortez A., Pinheiro S.R. Ferreira F., Fávero A.C.M. \& Ferreira Neto J.S. 1997. Leptospirose bovina: níveis de ocorrência e sorotipos predominantes em rebanhos dos Estados de Minas Gerais, São Paulo, Rio de Janeiro, Paraná, Rio Grande do Sul e Mato Grosso do Sul. Período de janeiro a abril de 1996. Arqs Inst. Biológico, São Paulo, 23:406-407. 